Article

\title{
The Antioxidant Content of Coffee and Its In Vitro Activity as an Effect of Its Production Method and Roasting and Brewing Time
}

\author{
Maciej Górecki and Ewelina Hallmann *(D) \\ Institute of Human Nutrition Sciences, Department of Functional and Organic Food, Warsaw University of Life \\ Sciences, Nowoursynowska 159c, 02-776 Warsaw, Poland; maciej.gorecki@greencaffenero.pl \\ * Correspondence: ewelina_hallmann@sggw.pl; Tel.: +48-2259-370-36
}

Received: 24 March 2020; Accepted: 8 April 2020; Published: 10 April 2020

check for updates

\begin{abstract}
Coffee is one of the most popular beverages in the world. The high production and health properties of coffee make it one of the best among daily drinks. Coffee is wrongly identified as only a stimulant because of its caffeine content. On the other hand, coffee is one of the best sources of other bioactive compounds, such as flavonoids and phenolic acids. Organic coffee is produced without artificial fertilizers and pesticides. Not only the high quality of beans but also roasting and brewing times guarantee the best taste and quality of coffee beverages. The aim of the present experiment was to determine the best level of roasting and brewing time for organic and conventional coffee. The experiment was carried out with Peru coffee beans from organic and conventional farms. The contents of caffeine and bioactive compounds were measured in different roasted and brewed coffee drinks. The obtained results showed that the conventional coffee contained significantly more caffeine, total flavonoids, and quercetin derivatives than the organic coffee. On the other hand, the organic coffee was characterized by a higher level of almost all bioactive compounds. The best level of roasting was determined to be medium, and the optimal brewing time was 3 minutes.
\end{abstract}

Keywords: organic coffee; conventional coffee; polyphenols; caffeine; brewing time; roasting time

\section{Introduction}

Coffee is one of the most popular crops in the world. The highest producers of raw green coffee in 2017 were Brazil (2.68 MT), Vietnam (1.54 MT), and Colombia (0.75 MT). In the case of organic coffee, Indonesia (0.50 MT), Ethiopia (0.35 MT), and Mexico (0.12 MT) produced the most raw green coffee [1]. The quality of coffee is determined by many factors, such as the type of production (organic or conventional), plantation localization, and agrotechnical conditions [2,3]. The next steps in production that affect coffee quality are roasting and brewing times. It seems that roasting time yielding a medium roast was the best for coffee bean quality [4]. Appropriate selection of coffee roasting temperature and time has an impact on the stability of polyphenolic compounds and their antioxidant activity [5]. At the same time, the use of modern technologies in food production lowers the quality of the final product [6,7]. Coffee is rich in bioactive compounds, not only caffeine. Among the phenolic antioxidants, coffee provides a high content of phenolic acids of the hydroxycinnamic acid family (caffeic, chlorogenic, $p$-coumaric, and ferulic acids). Many studies reflect the phenolic acid content in green coffee (chlorogenic acid content) or roasted coffee (other phenolic acids). Only a few studies have focused on the flavonoid content in the final product [8-10]. Bioactive compounds in coffee are responsible for many biological actions, such as chemo-protective effects, antioxidant and anti-inflammatory properties, and anticancer activity [11-14]. Regular brewed coffee consumption protects the human body against many chronic diseases, including cardiovascular disease, obesity, some types of cancer, and type 2 diabetes [15-17]. Organic coffee production is based on 
not using mineral fertilizers and artificial plant protectors (pesticides). Only natural methods of plant protection and fertilization are allowed in organic farming. Because coffee plants are without chemical protection, plants produce more phenolic compounds, better known as "natural pesticides" [18,19]. In the modern literature, there has been no research on the quality of organic coffee, especially the phenolic profile, or their quantity and quality in comparison to those in conventional coffee. For that reason, the main aim of the presented experiment is to show how the content and profile of polyphenolic compounds belonging to different chemical classes, as well as the antioxidant capacity, were determined in different roasted and brewed organic and conventional coffee samples.

\section{Materials and Methods}

\subsection{Chemicals}

ABTS (2,2'-Azino-bis(3-ethylbenzothiazoline-6-sulfonic acid) diammonium salt (Sigma-Aldrich, Poland); acetonitrile (Sigma-Aldrich, Poland); deionized water (Sigma-Aldrich, Poland); ethyl acetate (Merck, Poland); methanol (Merck, Poland); ortho-phosphoric acid (Chempur, Poland); phenolic compound standards (purity 99.5\%-99.9\%), including caffeic acid, chlorogenic acid, epigallocatechin, gallic acid, kaempferol, kaempferol-3-O-glucoside, quercetin, quercetin-3-O-glucoside, quercetin-3-O-rutinoside, and salicylic acid (Sigma-Aldrich, Poland); caffeine (Merck, Poland); and phosphate-buffered saline (Merck, Poland) were used in this study.

\subsection{Coffee Bean Origin}

Green coffee was purchased from a production company in Peru. The conventional coffee cultivation region was Cajamarca $\left(06^{\circ} 14^{\prime} \mathrm{S} 78^{\circ} 47^{\prime} \mathrm{W}\right)$, and the species was Coffea arabica ssp. Typica Bourbon. The first treatment included washing and drying in the sun. The organic coffee cultivation region was Mendoza ( $\left.32^{\circ} 53^{\prime} \mathrm{S} 68^{\circ} 49^{\prime} \mathrm{W}\right)$, and the species was Coffea arabica ssp. Typica Bourbon. The first treatment included washing and drying in the sun. Weather condition for both places of coffee cultivation are presented in Table S1.

\subsection{Coffee Roasting}

All technical parameters for coffee roasting are presented in Table 1.

Table 1. Coffee roasting parameters.

\begin{tabular}{ccccc}
\hline Roasting Day & \multicolumn{2}{c}{ 23 of November 2019 } & \multicolumn{2}{c}{ 23 of November 2019 } \\
\hline \multirow{2}{*}{ Coffee Type } & \multicolumn{2}{c}{ Conventional Coffee } & \multicolumn{2}{c}{ Organic Coffee } \\
\hline \multirow{5}{*}{ Light roasting } & Weight of green coffee: & $200 \mathrm{~g}$ & Weight of green coffee: & $165 \mathrm{~g}$ \\
\cline { 2 - 5 } & Roaster temperature: & $186.5^{\circ} \mathrm{C}$ & Roaster temperature: & $186.5^{\circ} \mathrm{C}$ \\
\cline { 2 - 5 } & First crack & $6: 40 \mathrm{~min}$. & First crack & $4: 40 \mathrm{~min}$ \\
\cline { 2 - 5 } & Roasting time & $7: 15 \mathrm{~min}$. & Roasting time & $6: 40 \mathrm{~min}$ \\
\cline { 2 - 5 } & Coffee weight after roasting: & $177.7 \mathrm{~g}$ & Coffee weight after roasting: & $145.3 \mathrm{~g}$ \\
\cline { 2 - 5 } & Coffee weight lost & $22.3 \mathrm{~g}$ & Coffee weight lost & $19.7 \mathrm{~g}$ \\
\cline { 2 - 5 } & Roasting process efficiency & $88.85 \%$ & Roasting process efficiency & $88.06 \%$ \\
\cline { 2 - 5 } Medium roasting & Weight of green coffee: & $200 \mathrm{~g}$ & Weight of green coffee: & $165 \mathrm{~g}$ \\
\cline { 2 - 5 } & Roaster temperature: & $186.5{ }^{\circ} \mathrm{C}$ & Roaster temperature: & $186.5{ }^{\circ} \mathrm{C}$ \\
\cline { 2 - 5 } & First crack & $6: 20 \mathrm{~min}$ & First crack & $5: 05 \mathrm{~min}$ \\
\cline { 2 - 5 } & Roasting time & $8: 25 \mathrm{~min}$ & Roasting time & $7: 55 \mathrm{~min}$ \\
\cline { 2 - 5 } & Coffee weight after roasting: & $175.0 \mathrm{~g}$ & Coffee weight after roasting: & $141.9 \mathrm{~g}$ \\
\cline { 2 - 5 } & Coffee weight lost & $25 \mathrm{~g}$ & Coffee weight lost & $23.1 \mathrm{~g}$ \\
\cline { 2 - 5 } & Roasting process efficiency & $87.50 \%$ & Roasting process efficiency & $86.00 \%$ \\
\hline
\end{tabular}


Table 1. Cont.

\begin{tabular}{|c|c|c|c|c|}
\hline Roasting Day & \multicolumn{2}{|c|}{23 of November 2019} & \multicolumn{2}{|c|}{23 of November 2019} \\
\hline Coffee Type & \multicolumn{2}{|c|}{ Conventional Coffee } & \multicolumn{2}{|l|}{ Organic Coffee } \\
\hline \multirow{7}{*}{ Dark roasting } & Weight of green coffee: & $200 \mathrm{~g}$ & Weight of green coffee: & $165 \mathrm{~g}$ \\
\hline & Roaster temperature: & $186.5^{\circ} \mathrm{C}$ & Roaster temperature: & $186.5^{\circ} \mathrm{C}$ \\
\hline & First crack & 6:05 min & First crack & $5: 10 \mathrm{~min}$ \\
\hline & Roasting time & $14: 02 \mathrm{~min}$ & Roasting time & $13: 46 \mathrm{~min}$ \\
\hline & Coffee weight after roasting: & $162.3 \mathrm{~g}$ & Coffee weight after roasting: & $135.2 \mathrm{~g}$ \\
\hline & Coffee weight lost & $37.7 \mathrm{~g}$ & Coffee weight lost & $29.8 \mathrm{~g}$ \\
\hline & Roasting process efficiency & $81.15 \%$ & Roasting process efficiency & $81.93 \%$ \\
\hline
\end{tabular}

\subsection{Polyphenol Analysis}

The quantitative and qualitative analysis of polyphenols was carried out by the HPLC method described earlier in detail by Król et al. [4]. Briefly, three roasting levels were evaluated, and ground coffee samples $(5 \mathrm{~g})$ were brewed in hot deionized water $\left(90^{\circ} \mathrm{C}, 100 \mathrm{~mL}\right)$. Two brewing times were chosen: 3 minutes and 6 minutes. After that time, the coffee was filtered through a soft filter and funnel into a glass flask. One millilitre of extract was used for polyphenol analysis.

\subsection{Antioxidant Activity Analysis}

Five grams of the ground coffee sample was weighed into a sterile plastic falcon tube, and $25 \mathrm{~mL}$ of deionized water was added. The tube was placed onto a Vortexer (Labo Plus, Warsaw, Poland) for 1 minute at $2000 \mathrm{rpm}$. Subsequently, the sample was incubated in a shaker incubator IKA KS 4000 (Staufen im Breisgau, Germany) for $1 \mathrm{~h}$ (temperature $30^{\circ} \mathrm{C}, 6 \times \mathrm{g}$ ). Next, the sample was vortexed again for $1 \mathrm{~min}$ for complete mixing and then centrifuged in a MPW-380 R centrifuge (Warsaw, Poland) at $2{ }^{\circ} \mathrm{C}$ and $16,250 \times \mathrm{g}$ for $15 \mathrm{~min}$. In the next step, only the supernatant was used for analysis. In $10 \mathrm{~mL}$ glass tubes, test extract solution, measured with a predetermined dilution scheme $(0.5-1.5 \mathrm{~mL})$, was then added to $3.0 \mathrm{~mL}$ of ABTS-+ cationic solution in PBS (phosphate-buffered saline). Absorbance measurements were taken exactly 6 minutes after incubation at $21^{\circ} \mathrm{C}$ at the wavelength of $734 \mathrm{~nm}$ using a spectrophotometer (Helios $\gamma$, Thermo Scientific, Warsaw, Poland). The obtained measurements were calculated using a formula including the dilution factor. The final results are expressed as mmol of TE (Trolox equivalents per $100 \mathrm{~mL}$ of brewed coffee) [20].

\subsection{Statistical Analysis}

The results obtained from chemical measurements were statistically evaluated with Statgraphics Centurion 15.2.11.0 software (StatPoint Technologies, Inc., Warranton, VA, USA). The values presented in the table are expressed as the mean values for organic and conventional coffee production, three roasting levels (light, medium, and dark), and two brewing times ( 3 minutes and 6 minutes). The statistical calculations were based on three-way analysis of variance with the use of Tukey's test $(p=0.05)$. A lack of statistically significant differences between the examined groups is indicated by similar letters. The standard error (SE) is provided with each mean value reported in the tables. Principal component analysis (PCA) was carried out using XLSTAT Software (XLSTAT, 2020, New York, NY, USA) to categorize the coffee samples roasted and brewed at different times based on their bioactive compound and caffeine contents.

\section{Results and Discussion}

One of the best-known bioactive compounds in coffee is caffeine. The concentration of this alkaloid depends on many factors, such as coffee origin and roasting and brewing times. In our experiment, the organic coffee contained significantly less caffeine $\left(48.1 \mathrm{mg} 100 \mathrm{~mL}^{-1}\right)$ than the conventional coffee (57.9 mg $100 \mathrm{~mL}^{-1}$ ) (Table 2). 


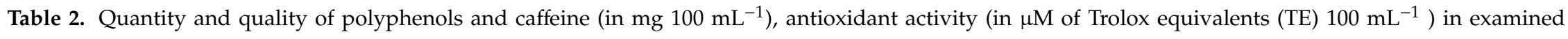
coffee samples.

\begin{tabular}{|c|c|c|c|c|c|c|c|c|c|c|}
\hline \multirow{2}{*}{ Compounds/Combination } & \multicolumn{2}{|c|}{ Coffee Origin } & \multicolumn{3}{|c|}{ Coffee Roasting } & \multicolumn{2}{|c|}{ Coffee Brewing } & \multicolumn{3}{|c|}{$p$-Value } \\
\hline & Organic Coffee & Conventional Coffee & Light & Medium & Dark & 3 Min & 6 Min & Origin & Roasting & Brewing \\
\hline caffeine & $48.10 \pm 3.95 b$ & $57.95 \pm 5.39 a$ & $72.96 \pm 1.57 \mathrm{a}$ & $58.25 \pm 3.75 b$ & $27.87 \pm 1.43 c$ & $54.76 \pm 4.49 a$ & $51.29 \pm 5.19 b$ & $<0.0001$ & $<0.0001$ & 0.0022 \\
\hline total polyphenols & $104.18 \pm 2.15 \mathrm{a}$ & $.80 \pm 1.94 \mathrm{~b}$ & $88.54 \pm 4.87 \mathrm{~b}$ & $98.71 \pm 4.17 \mathrm{a}$ & $91.71 \pm 2.12 \mathrm{a}$ & $93.54 \pm 3.28 \mathrm{a}$ & $92.44 \pm 3.39 \mathrm{~b}$ & $<0.0001$ & $<0.0001$ & 0.0026 \\
\hline total phenolic acids & $97.51 \pm 2.17 \mathrm{a}$ & $75.16 \pm 2.39 b$ & $79.97 \pm 5.12 \mathrm{c}$ & $92.42 \pm 4.11 \mathrm{a}$ & $86.62 \pm 2.25 b$ & $87.07 \pm 3.52 a$ & $85.60 \pm 3.44 \mathrm{~b}$ & $<0.0001$ & $<0.0001$ & 0.044 \\
\hline chlorogenic acid & $54.09 \pm 5.45 \mathrm{a}$ & $36.94 \pm 3.38 \mathrm{~b}$ & $59.37 \pm 5.06 a$ & $56.21 \pm 2.19 \mathrm{a}$ & $20.96 \pm 2.20 b$ & $45.79 \pm 3.93 a$ & $45.24 \pm 5.82 a$ & $<0.0001$ & & N.S. \\
\hline caffei & $30.49 \pm 3.58 \mathrm{a}$ & $25.62 \pm 4.40 \mathrm{~b}$ & $11.22 \pm 0.38 c$ & $22.30 \pm 2.21 \mathrm{~b}$ & $50.64 \pm 0.38 \mathrm{a}$ & $28.37 \pm 3.98 \mathrm{a}$ & $27.74 \pm 4.13 a$ & $<0.0001$ & & N.S. \\
\hline & $3.99 \pm 0.25 a$ & $3.54 \pm 0.25 \mathrm{~b}$ & $2.37 \pm 0.07 \mathrm{~b}$ & $4.48 \pm 0.09 \mathrm{a}$ & $4.44 \pm 0.20 \mathrm{a}$ & $3.82 \pm 0.26 \mathrm{a}$ & $3.71 \pm 0.25 b$ & $<0.0001$ & $<0.0001$ & 0.0039 \\
\hline total flavonoids & $6.67 \pm 0.25 a$ & $6.63 \pm 0.49 a$ & $8.58 \pm 0.25 a$ & $6.30 \pm 0.06 \mathrm{~b}$ & $5.09 \pm 0.32 c$ & $6.46 \pm 0.43 \mathrm{~b}$ & $6.84 \pm 0.34 a$ & N.S. & $<0.0001$ & $<0.0001$ \\
\hline epigallocatechin & $0.728 \pm 0.02 \mathrm{a}$ & $0.717 \pm 0.03 b$ & $0.680 \pm 0.01 \mathrm{~b}$ & $0.861 \pm 0.01 \mathrm{a}$ & $0.628 \pm 0.01 \mathrm{~b}$ & $0.699 \pm 0.02 b$ & $0.747 \pm 0.02 \mathrm{a}$ & 0.006 & $<0.0001$ & $<0.0001$ \\
\hline kaempferol-3-O-glucoside & $0.980 \pm 0.18 \mathrm{a}$ & $0.959 \pm 0.23 \mathrm{~b}$ & $1.803 \pm 0.16 a$ & $0.332 \pm 0.02 c$ & $0.772 \pm 0.27 \mathrm{~b}$ & $0.793 \pm 0.18 b$ & $1.146 \pm 0.22 \mathrm{a}$ & 0.0113 & $<0.0001$ & $<0.0001$ \\
\hline quercetin & $0.87 \pm 0.02 a$ & $0.86 \pm 0.02 \mathrm{~b}$ & $0.86 \pm 0.02 \mathrm{~b}$ & $0.80 \pm 0.01 \mathrm{~b}$ & $0.94 \pm 0.02 \mathrm{a}$ & $0.87 \pm 0.02 \mathrm{a}$ & $0.86 \pm 0.02 \mathrm{a}$ & 0.044 & $<0.0001$ & N.S. \\
\hline quercetin-3-O-glucoside & $2.20 \pm 0.09 b$ & $2.28 \pm 0.16 a$ & $2.88 \pm 0.08 a$ & $2.19 \pm 0.04 a$ & $1.64 \pm 0.06 b$ & $2.26 \pm 0.15 a$ & $2.22 \pm 0.11 \mathrm{a}$ & 0.0001 & $<0.0001$ & N.S. \\
\hline kaempferol & $0.96 \pm 0.04 a$ & $0.76 \pm 0.01 \mathrm{~b}$ & $0.82 \pm 0.02 \mathrm{~b}$ & $1.00 \pm 0.05 \mathrm{a}$ & $0.77 \pm 0.02 b$ & $0.85 \pm 0.04 \mathrm{~b}$ & $0.87 \pm 0.04 a$ & $<0.0001$ & $<0.0001$ & 0.005 \\
\hline antioxidant activity & $3069.93 \pm 27.0 \mathrm{a}$ & $2940.54 \pm 30.7 b$ & $3022.45 \pm 30.3 a$ & $3036.69 \pm 39.1 \mathrm{a}$ & $2956.57 \pm 45.4 b$ & $3061.62 \pm 38.5 \mathrm{a}$ & $2948.85 \pm 17.4 b$ & $<0.0001$ & $<0.0001$ & $<0.0001$ \\
\hline
\end{tabular}

Data are presented as the mean \pm SE with ANOVA $p$-value; means in rows followed by the same letter are not significantly different at the $5 \%$ level of probability $(p<0.05)$; N.S. not significant statistically; $(n=9)$. 
This was probably due to the chemical structure of that compound. Caffeine is a purine alkaloid. Its concentration in coffee beans depends exactly on the nitrogen fertilization used in cultivation as well as the phloem nitrogen concentration. Coffee plants with high levels of nitrogen fertilization produced coffee beans with high caffeine concentrations [21]. Organic coffee plants are cultivated without easily available nitrogen fertilizers. Only natural organic fertilizers are allowed. Using this kind of organic matter changes the $\mathrm{C} / \mathrm{N}$ ratio in plants [22]. This leads to higher concentrations of nitrogen-containing secondary metabolites in plants, such as caffeine. This phenomenon is explained by $\mathrm{C} / \mathrm{N}$ balance theory. Under natural conditions, when nitrogen is readily available (conventional agriculture), plants primarily make compounds with high nitrogen concentrations (proteins; amino acids for growth; and $\mathrm{N}$-containing secondary metabolites, such as alkaloids). When nitrogen availability is limited during growth (organic agriculture), the metabolism changes by incorporating more carbon (C)-containing flavonoid compounds [23]. We observed that longer roasting times significantly decreased the level of caffeine in the examined samples. A similar effect was presented in another experiment [24]. The medium roasting level exhibited the smallest change in caffeine content in hot brewed coffee (Table 2). On the other hand, the length of coffee brewing plays a significant role in the caffeine content. In the first three minutes of coffee brewing, we observed a significantly ( $p=0.0022)$ higher concentration of caffeine in the brewed coffees. Our results were in accordance with published previous results [25]. This was due to the higher concentration of caffeine at the beginning of brew preparation. Over time, the caffeine content decreased because it was inactivated by secretes polyphenolic compounds that formed caffeine-phenolic compound complexes [26]. In the present experiment, we observed this phenomenon. We found a strong correlation between the decreasing content of caffeine and the increasing content of polyphenols in the brewed coffee (Figure $1 \mathrm{~A}-\mathrm{D})$. The organic coffee contained significantly more total polyphenols $(p<0.0001)$ and total phenolic acids $(p<0.0001)$ than the conventional samples (Table 2$)$. Similar results were presented in the next experiment with coffee [4]. Organic coffee contained more phenolic compounds than conventional coffee, with values of $44.8 \mathrm{mg} 100 \mathrm{~mL}^{-1}$ and $41.4 \mathrm{mg} 100 \mathrm{~mL}^{-1}$, respectively. This effect could be due to the higher concentration of secondary metabolites in organic plants because of their self-protection against pests and diseases [27,28]. The medium-roasted coffee beans contained significantly more total polyphenols $(p<0.0001)$ and total phenolic acids $(p<0.0001)$ than the dark- or light-roasted beans. In the other two levels of roasting (light and dark), we observed a decreases phenolic compound content compared to that of the medium-roasted beans (Table 2). On the other hand, high temperature and modern technologies could be effectively used to recover thermally labile and nonpolar bioactive ingredients and use them for different purposes, for example, caffeine in cosmetics [29-31]. The length of coffee brewing plays a significant role in the polyphenol concentration in coffee beverages. In the short brewing time, we observed significantly higher concentrations of total polyphenols $(p=0.0026)$ and total phenolic acids $(p=0.044)$ than with longer brewing times. This can be explained by the formation of caffeine-phenolic compound complexes, which was discussed above in light of the caffeine content [32]. The main phenolic acid present in coffee beans is chlorogenic acid. In our experiment, we noticed that the organic coffee contained significantly more chlorogenic $(p<0.0001)$, caffeic $(p<0.0001)$, and salicylic $(p<0.0001)$ acids than the conventional coffee. A similar situation was reported in another experiment [4]. Notably, the roasting method significantly reduced the level of chlorogenic acid $(p<0.0001)$ in coffee beverages. The highest difference was observed between the light- and dark-roasted samples (Table 2). The organic coffee contained significantly more salicylic acid $(p<0.0001)$ than the conventional coffee. Salicylic acid is one of the most important phenolic compounds produced by Coffea arabica plants as a defence against Colletotrichum kahawae [33]. Organic plants are cultivated without artificial plant protectors (pesticides). Therefore, the level of phytochemicals in their tissues must be higher than those in conventional plants. The roasting time influenced the caffeic and salicylic acid contents. In the dark-roasted samples, we noticed a significantly $(p<0.0001)$ higher salicylic acid content than that in the light- and medium-roasted beans. Increased roasting increased the salicylic acid concentration in the final product [4]. Similar results were confirmed by Pelvan et al. (2018) [34]. Higher temperatures during nut roasting also increased the 
level of salicylic acid in the final product. Coffee prepared with a short brewing time was characterized by a higher level of salicylic acid $\left(3.82 \mathrm{ng} 100 \mathrm{~mL}^{-1}\right)$ than that brewed for longer $\left(3.71 \mathrm{mg} 100 \mathrm{~mL}^{-1}\right)$.

The organic coffee contained similar concentrations of total flavonoids as the conventional coffee. Contrary results were reported by some researchers [3,4]. In their experiments, organic coffee contained more total flavonoids than conventional coffee. In our experiment, only the coffee roasting and brewing times significantly influenced the total flavonoid content in the examined beverages (Table 2). The concentration of total flavonoids was the highest with light roasting $\left(8.6 \mathrm{mg} 100 \mathrm{~mL}^{-1}\right)$ compared to medium (6.3 mg $100 \mathrm{~mL}^{-1}$ ) and dark roasting $\left(5.1 \mathrm{mg} 100 \mathrm{~mL}^{-1}\right)$. After $6 \mathrm{~min}$ of brewing, we obtained a higher concentration of total flavonoids in the prepared beverages than after 3 minutes of brewing. One experiment examined the kinetics of flavonoid release from tea leaves into beverages. A much higher concentration was observed after a long extraction time $(8 \mathrm{~min})$ compared to a short extraction time (4 min) [35]. We think that, in our case of coffee samples, we were observing a similar phenomenon. The flavonoids present in the coffee showed different concentrations according to brewing time. Based on this knowledge, we can recommend the best brewing time for the type of coffee. The organic coffee contained significantly more kaempferol $(p<0.0001)$ and kaempferol-3-O-glucoside $(p<0.0001)$ than the conventional coffee. A similar effect was reported by in the next experiment with coffee [4]. In the case of quercetin and its derivatives, we observed that a longer roasting time changes the ratio of glycosidic forms to aglycone forms. This could be because a longer roasting time breaks down glycoside bonds. In the light-roasted coffee beans, the glycosidic forms of quercetin predominated, but in the dark-roasted coffee beans, only the quercetin aglycone forms were present. The thermal treatment of onions led to degradation of quercetin glycosides [36]. The main product was the aglycone quercetins, which remained stable during further roasting.

Antioxidant activity is a main factor reflecting the bioactive compound content in the examined coffee samples. The organic coffee had a higher antioxidant status $(p<0.0001)$ than the conventional coffee (Table 2). Based on the obtained results, it seemed that only the medium roasting stage was best for coffee preparation. The antioxidant power of coffee samples prepared with medium-roasted beans yielded the highest antioxidant effect compared to that of the coffee brewed with the light- and dark-roasted beans. A short time of coffee brewing $(3 \mathrm{~min})$ resulted in the highest concentration of polyphenols $(p<0.0001)$ in comparison to those observed after $6 \mathrm{~min}$ of brewing. In our experiment, we found a strong correlation between antioxidant activity and polyphenol content. A strong correlation was observed for conventional samples at both brewing times: 3 min $\left(R^{2}=0.8654\right)$ and 6 minutes $\left(R^{2}=0.9646\right)$ (Figure 2). On the other hand, we observed the formation of caffeine-polyphenol complexes. Both compounds were blocked together, as we pointed out in the case of caffeine. We also observed a relationship between decreasing polyphenol status and increasing caffeine content in the experimental coffee samples (Figure 1). It is also known that there is an interaction between caffeine and polyphenols that is present in the preparation of black tea [37]. We confirmed that this was observed in our coffee samples. 

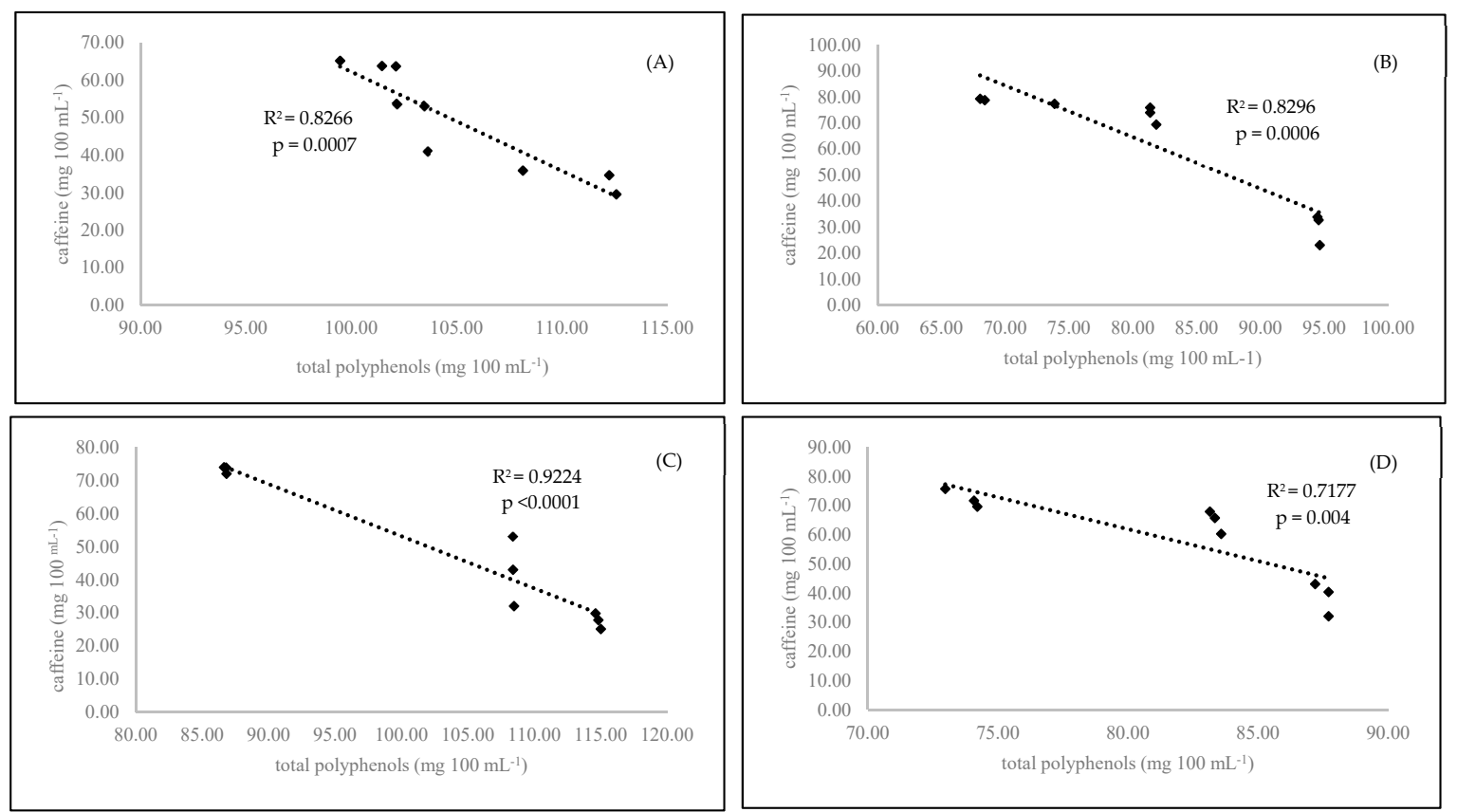

Figure 1. Linear regression (Pearson's coefficient $\mathrm{R}^{2}$ ) between caffeine and total polyphenols in organic 3-minutes-brewing coffee (A), conventional 3-minutes-brewing coffee (B), conventional 6-minutes-brewing coffee (C), and conventional 6-minutes-brewing coffee (D).
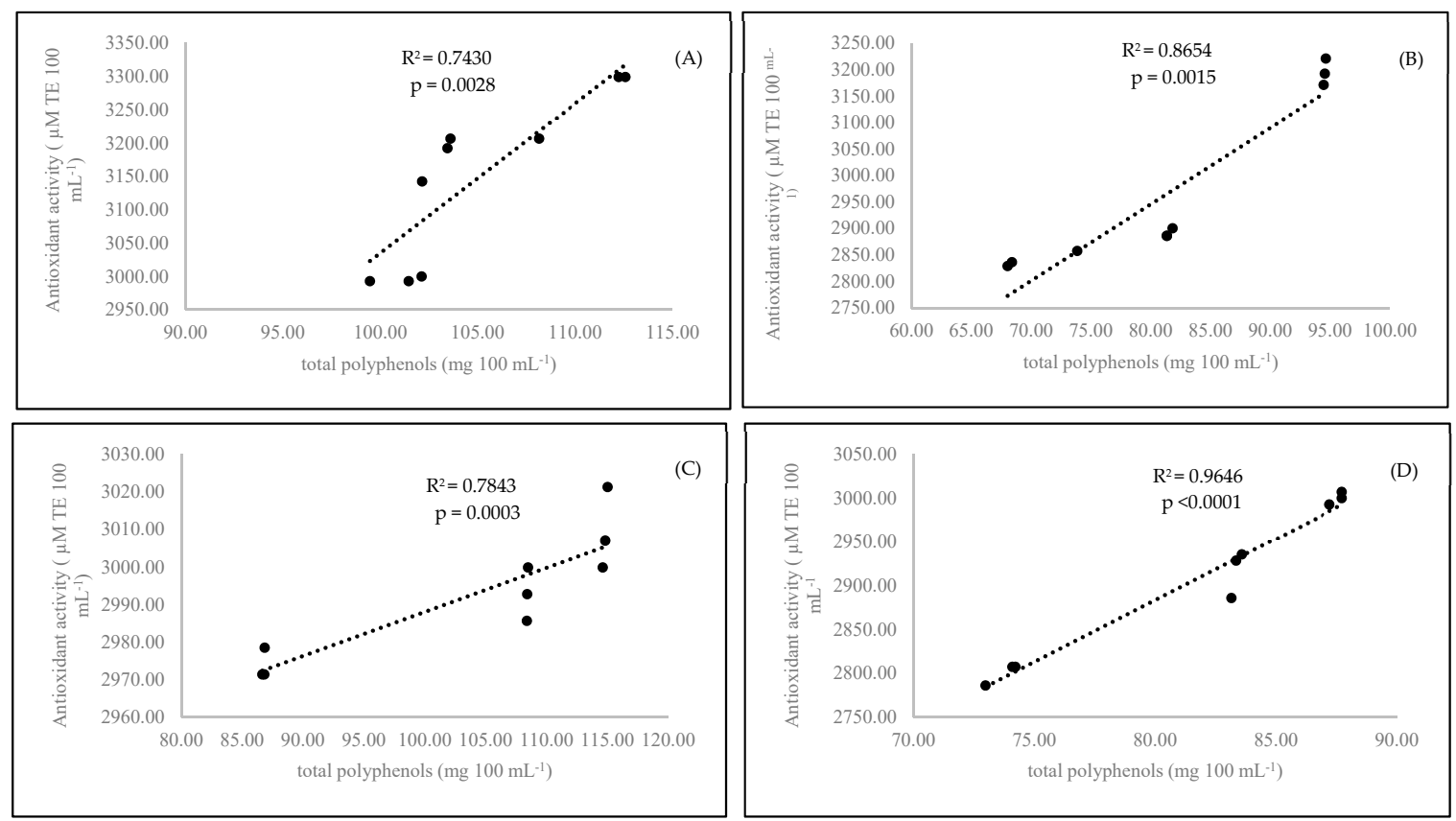

Figure 2. Linear regression (Pearson's coefficient $\mathrm{R}^{2}$ ) between antioxidant activity and total polyphenols in organic 3-minutes-brewing coffee (A), conventional 3-minutes-brewing coffee (B), conventional 6-minutes-brewing coffee (C), and conventional 6-minutes-brewing coffee (D).

PCA showed a high and significant overall variation of $71.56 \%$ that was explained by PC1 and PC2 (Figure 3). The degree of dependence between the organic coffee preparation method and the factors marked as antioxidant activity (AA) and caffeine (CaF), chlorogenic acid (ChlA), epigalocatechin (EGC), kaempferol (K), total polyphenol (TP), and total phenolic acid (TPA) contents was particularly important (Figure 3). 


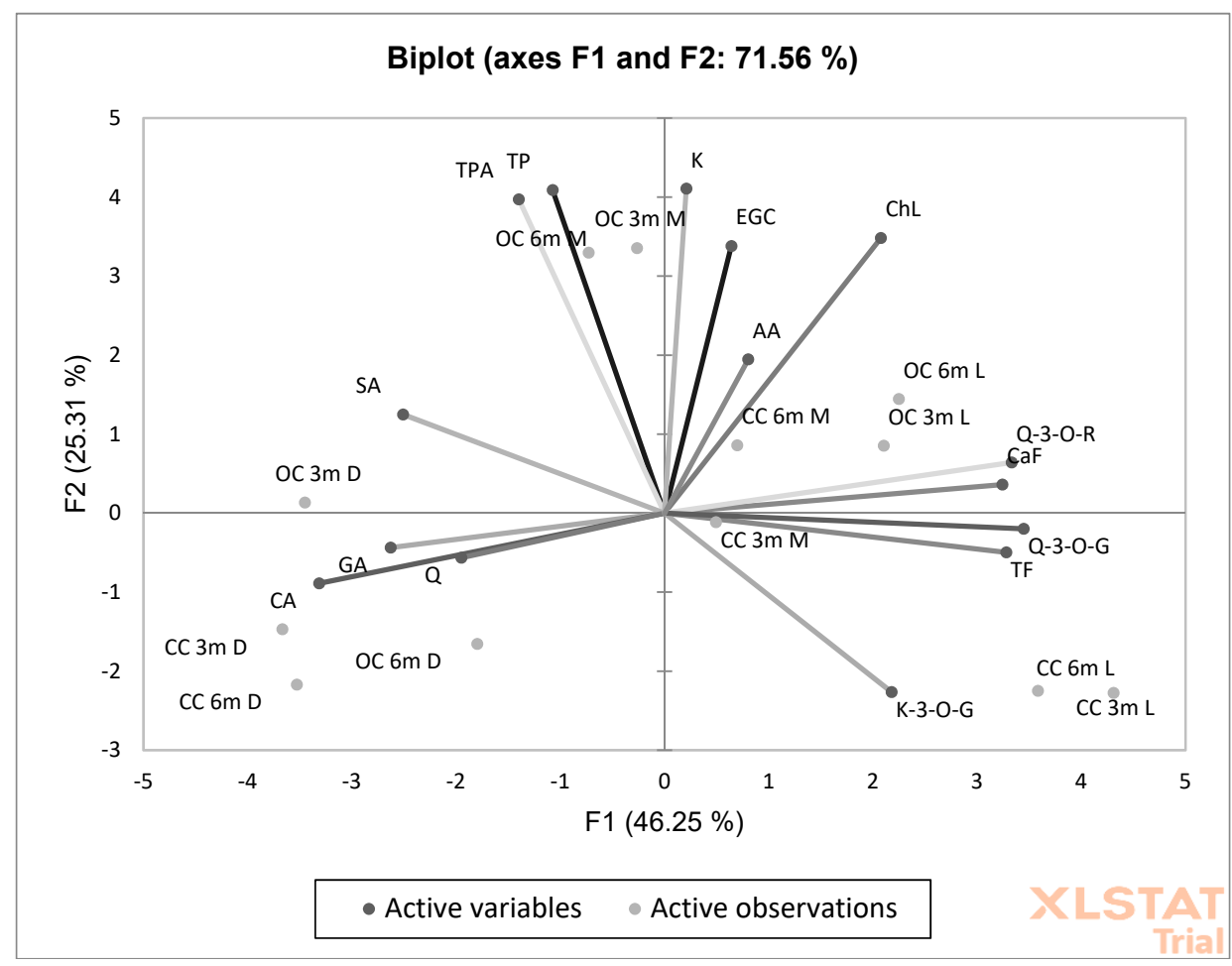

Figure 3. Principal component analysis (PCA) analysis showing the relationship between the chemical composition and roasting and brewing times in organic and conventional coffee. (CaF) caffeine; (TP) total polyphenols; (TPA) total phenolic acids; (GA) gallic acid; (ChL) chlorogenic acid; (CA) caffeic acid; (SA) salicylic acid; (FA); (TF) total flavonoids; (TFl) total flavonols; (EGC) epigallocatechin; (Q-3-O-R) quercetin-3-O-rutinoside; (Q-3-O-G) quercetin-3-O-glucoside; (K-3-O-G) kaempferol-3-O-glucoside; (Q) quercetin; (K) kaempferol.

\section{Conclusions}

In the present study, we confirmed that organic coffee presented a different quantity of polyphenol compounds compared to the conventional one. However, other factors, such as roasting and brewing times, appeared to have an important effect on the quality and quantity of bioactive compounds in coffee beverages. It is worth pointing out that many results highlighted the impact of coffee bean roasting rather than that of brewing time or coffee origin. The choice of a proper coffee preparation technique has a significant impact on the polyphenol and caffeine contents of coffee beverages.

Supplementary Materials: The supplementary materials are available online at http://www.mdpi.com/20763921/9/4/308/s1, Figure S1: The weather condition in time of coffee cultivation in two experimental production plantations in 2019 .

Author Contributions: Conceptualization, E.H., M.G.; data curation, M.G.; formal analysis E.H., M.G.; funding acquisition, E.H.; methodology, E.H.; project administration E.H.; resources M.G.; supervision E.H.; validation E.H., visualization E.H.; writing original draft M.G., E.H., All authors have read and agreed to the published version of the manuscript.

Funding: This research received no external funding

Acknowledgments: This paper has been published with the support of the Polish Ministry of Higher Education within the foundation of the Institute of Human Nutrition Sciences, Warsaw University of Life Sciences (WULS), for scientific research.

Conflicts of Interest: The authors declare no conflict of interest. 


\section{References}

1. Faostat Database. Available online: http://www.fao.org/faostat/en/\#home (accessed on 15 March 2020).

2. Cardoso, R.G.S.; Pedrosa, A.W.; Rodrigues, M.C.; Santos, R.H.S.; Martinez, H.E.P.; Cecon, P.R. Intercropping period between species of green manures and organically-fertilized coffee plantation. Coffee Sci. 2018, 13, 2-9. [CrossRef]

3. Ozuna, C.; Mulík, S.; Valdez-Rodríguez, B.; Abraham-Juárez, M.D.R.; Fernández-López, C.L. The effect of organic farming on total phenols, total flavonoids, brown compounds and antioxidant activity of spent coffee grounds from Mexico. Biol. Agric. Hortic. 2019, 1-12. [CrossRef]

4. Król, K.; Gantner, M.; Tatarak, A.; Hallmann, E. The effect of roasting, storage, origin on the bioactive compounds in organic and conventional coffee (Caffea arabica). Eur. Food Res. Technol. 2019, 246, 33-39. [CrossRef]

5. Zinoviadou, K.G.; Galanakis, C.M.; Brnčić, M.; Grimi, N.; Boussetta, N.; Mota, M.J.; Saraivae, J.A.; Patrasf, A.; Tiwari, B.; Barba, F.J. Fruit juice sonication: Implications on food safety and physicochemical and nutritional properties. Food Res. Int. 2015, 77, 743-752. [CrossRef]

6. Barba, F.J.; Galanakis, C.M.; Esteve, M.J.; Frigola, A.; Vorobiev, E. Potential use of pulsed electric technologies and ultrasounds to improve the recovery of high-added value compounds from blackberries. J. Food Eng. 2015, 167, 38-44. [CrossRef]

7. Galanakis, C.M. Emerging technologies for the production of nutraceuticals from agricultural by-products: A viewpoint of opportunities and challenges. Food Bioprod. Process. 2013, 91, 575-579. [CrossRef]

8. Ullah, R.; Ahmad, S.; Atiq, A.; Hussain, H.; Ur Rehman, N.; Abd Elsalam, N.; Adnan, M. Quantification and antibacterial activity of flavonoids in coffee samples. AJTCAM 2015, 12, 84-86. [CrossRef]

9. Lee, M.; McGeer, E.G.; McGeer, P.L. Quercetin, not caffeine, is a major neuroprotective component in coffee. Neurobiol. Aging 2016, 46, 113-123. [CrossRef]

10. Niseteo, T.; Komes, D.; Belščak-Cvitanović, A.; Horžić, D.; Budeč, M. Bioactive composition and antioxidant potential of different commonly consumed coffee brews affected by their preparation technique and milk addition. Food Chem. 2012, 134, 1870-1877. [CrossRef]

11. Soares, P.V.; Kannen, V.; Jordão Junior, A.A.; Garcia, S.B. Coffee, but neither decaffeinated coffee nor caffeine, elicits chemoprotection against a direct carcinogen in the colon of Wistar rats. Nutr. Cancer 2018, 1-9. [CrossRef]

12. Çelik, E.E.; Gökmen, V.A. Study on interactions between the insoluble fractions of different coffee infusions and major cocoa free antioxidants and different coffee infusions and dark chocolate. Food Chem. 2018, 255, 8-14. [CrossRef] [PubMed]

13. Chen, X.-M.; Ma, Z.; Kitts, D.D. Effects of processing method and age of leaves on phytochemical profiles and bioactivity of coffee leaves. Food Chem. 2018, 249, 143-153. [CrossRef] [PubMed]

14. Mojica, B.E.; Fong, L.E.; Biju, D.; Muharram, A.; Davis, I.M.; Vela, K.O.; Rios, D.; Osorio-Camacena, E.; Kaur, B.; Rojas, S.M.; et al. The Impact of the roast levels of coffee extracts on their potential anticancer activities. J. Food Sci. 2018, 83, 1125-1130. [CrossRef] [PubMed]

15. Gökcen, B.B.; Şanlier, N. Coffee consumption and disease correlations. Crit. Rev. Food Sci. Nutr. 2017, 1-13. [CrossRef]

16. Pimentel, G.D.; Micheletti, T.O.; Fernandes, R.C.; Nehlig, A. Coffee Intake and obesity. In Nutrition in the Prevention and Treatment of Abdominal Obesity; Academic Press: Cambridge, MA, USA, 2017; pp. 329-351.

17. Hu, Y.; Ding, M.; Yuan, C.; Wu, K.; Smith-Warner, S.A.; Hu, F.B.; Chan, A.T.; Meyerhardt, J.A.; Ogino, S.; Fuchs, C.S.; et al. Association between coffee intake after diagnosis of colorectal cancer and reduced mortality. Gastroenterology 2018, 154, 916-926. [CrossRef]

18. Xu, D.; Deng, Y.; Han, T.; Jiang, L.; Xi, P.; Wang, Q.; Jiang, Z.; Gao, L. In Vitro and In Vivo effectiveness of phenolic compounds for the control of postharvest gray mold of table grapes. Postharvest Biol. Technol. 2018, 139, 106-114. [CrossRef]

19. Sanzani, S.M.; Schena, L.; Ippolito, A. Effectiveness of phenolic compounds against citrus green mould. Molecules 2014, 19, 12500-12508. [CrossRef]

20. Średnicka-Tober, D.; Ponder, A.; Hallmann, E.; Głowacka, A.; Rozpara, E. The profile and content of polyphenols and carotenoids in local and commercial sweet cherry fruits (Prunus avium L.) and their antioxidant activity In Vitro. Antioxidants 2019, 8, 534. [CrossRef] 
21. Gonthier, D.J.; Witter, J.D.; Spongberg, A.L.; Philpott, S.M. Effect of nitrogen fertilization on caffeine production in coffee (Coffea arabica). Chemoecology 2011, 21, 123-130. [CrossRef]

22. Heimler, D.; Romani, A.; Ieri, F. Plant polyphenol content, soil fertilization and agricultural management: A review. Eur. Food Res. Technol. 2017, 243, 1107-1115. [CrossRef]

23. Hallmann, E.; Kazimierczak, R.; Marszałek, K.; Drela, N.; Kiernozek, E.; Toomik, P.; Matt, D.; Luik, A.; Rembiałkowska, E. The nutritive value of organic and conventional white cabbage (Brassica oleracea $\mathrm{L}$. var. capitata) and anti-apoptotic activity in gastric adenocarcinoma cells of sauerkraut juice produced therof. J. Agric. Food Chem. 2017, 65, 8171-8183. [CrossRef] [PubMed]

24. Fibrianto, K.; Umam, K.; Wulandari, E.S. Effect of roasting profiles and brewing methods on the characteristics of bali kintamani coffee. Adv. Eng. Res. 2017, 172, 194-197.

25. Głowacka, R.; Górska, A.; Wirkowska-Wojdyła, M.; Wołosiak, R.; Majewska, E.; Derewiaka, D. The influence of brewing method on bioactive compounds residues in spent coffee grounds of different roasting degree and geographical origin. Int. J. Food Sci. Technol. 2017, 54, 3008-3014. [CrossRef]

26. Shishikura, Y.; Khokhar, S. Factors affecting the levels of catechins and caffeine in tea beverage: Estimated daily intakes and antioxidant activity. J. Sci. Food Agric. 2005, 85, 2125-2133. [CrossRef]

27. Ranilla, L.G.; Kwon, Y.I.; Apostolidis, E.; Shetty, K. Phenolic compounds, antioxidant activity and In Vitro inhibitory potential against key enzymes relevant for hyperglycemia and hypertension of commonly used medicinal plants, herbs and spices in Latin America. Bioresour. Technol. 2010, 101, 4676-4689. [CrossRef]

28. Young, J.E.; Zhao, X.; Carey, E.E.; Welti, R.; Yang, S.-S.; Wang, W. Phytochemical phenolics in organically grown vegetables. Mol. Nutr. Food Res. 2005, 49, 1136-1142. [CrossRef]

29. Bursać Kovačević, D.; Barba, F.J.; Granato, D.; Galanakis, C.M.; Herceg, Z.; Dragović-Uzelac, V.; Putnik, P. Pressurized hot water extraction (PHWE) for the green recovery of bioactive compounds and steviol glycosides from Stevia rebaudiana Bertoni leaves. Food Chem. 2018, 254, 150-157. [CrossRef]

30. Galanakis, C.M. Phenols recovered from olive mill wastewater as additives in meat products. Trends Food Sci. Technol. 2018, 79, 98-105. [CrossRef]

31. Galanakis, C.M.; Tsatalas, P.; Galanakis, I.M. Implementation of phenols recovered from olive mill wastewater as UV booster in cosmetics. Ind. Crop. Prod. 2018, 111, 30-37. [CrossRef]

32. D'Amelio, N.; Fontanive, L.; Uggeri, F.; Suggi-Liverani, F.; Navarini, L. NMR reinvestigation of the caffeine-chlorogenate complex in aqueous solution and in coffee brews. Food Biophys. 2009, 4, 321-330. [CrossRef]

33. Alemu, K.; Adugna, G.; Lemessa, F.; Muleta, D. Induction of systemic resistance in Arabica coffee (Coffea arabica L.) against coffee berry disease (Colletotrichum kahawae Waller \& Bridge) mediated through plant defense activator. Int. J. Pest Manag. 2018, 65, 313-323.

34. Pelvan, E.; Olgun, E.Ö.; Karadağ, A.; Alasalvar, C. Phenolic profiles and antioxidant activity of Turkish Tombul hazelnut samples (natural, roasted, and roasted hazelnut skin). Food Chem. 2018, 244, 102-108. [CrossRef] [PubMed]

35. Fernando, C.D.; Soysa, P. Extraction Kinetics of phytochemicals and antioxidant activity during black tea (Camellia sinensis L.) brewing. Nutr. J. 2015, 14, 74. [CrossRef] [PubMed]

36. Rohn, S.; Buchner, N.; Driemel, G.; Rauser, M.; Kroh, L.W. Thermal degradation of onion quercetin glucosides under roasting conditions. J. Agric. Food Chem. 2007, 55, 1568-1573. [CrossRef] [PubMed]

37. Mahapatra, A.K.; Sahoo, P.; Goswami, S.; Fun, H.-K.; Yeap, C.S. First artificial acidic fluorescent receptors for caffeine and other xanthine alkaloids. J. Incl. Phenom. Macrocycl. 2009, 67, 99-108. [CrossRef]

(C) 2020 by the authors. Licensee MDPI, Basel, Switzerland. This article is an open access article distributed under the terms and conditions of the Creative Commons Attribution (CC BY) license (http://creativecommons.org/licenses/by/4.0/). 